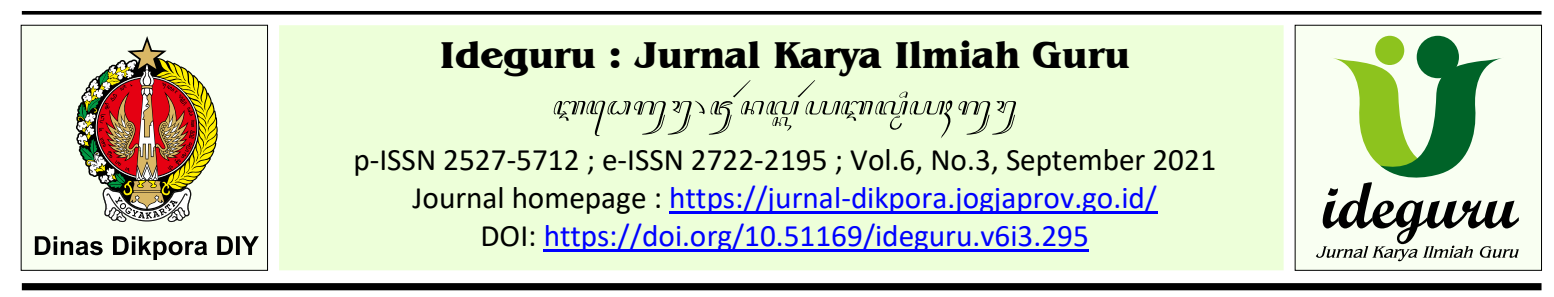

Artikel Penelitian - Naskah dikirim: 06/06/2021 - Selesai revisi: 02/08/2021 - Disetujui: 03/08/2021 - Diterbitkan: 01/09/2021

\title{
Penerapan Kelasiber Berbasis Video Pembelajaran Daring untuk Meningkatkan Keaktifan dan Hasil Belajar Fisika
}

\author{
Eko Mulyadi \\ SMK Negeri 3 Yogyakarta \\ ekomulyadi54@guru.smk.belajar.id
}

\begin{abstract}
Abstrak: Penelitian tindakan kelas ini bertujuan untuk meningkatkan keaktifan dan hasil belajar Fisika di kelas XTP2 SMKN 3 Yogyakarta dengan penerapan Kelasiber Berbasis Video Pembelajaran Daring Fisika Kompetensi Listrik Statis dan Listrik DC. Penelitian dilaksanakan dalam dua siklus, setiap siklus terdiri dari dua pertemuan, setiap pertemuan dengan alokasi waktu dua jam pelajaran. Setiap siklus meliputi perencanaan, tindakan, pengamatan, dan refleksi. Kelasiber Berbasis Video Pembelajaran Daring dengan langkah-langkah menginformasikan masuk kelasiber, pencarian video pembelajaran, peserta didik menyaksikan video, mengerjakan latihan soal, guru menganalisis keaktifan dan hasil belajar, umpan balik hasil belajar. Keaktifan diukur dari: Kehadiran tepat waktu, Kehadiran mengajukan pertanyaan, dan melihat video sedangkan aspek hasil belajar diukur dari tes. Hasil penelitian menunjukkan bahwa peningkatan keaktifan pada siklus I, ketepatan waktu sebesar $61,11 \%$, kehadiran $72,22 \%$, mengajukan pertanyaan $5,56 \%$, melihat video $44,44 \%$, pada siklus II ketepatan waktu sebesar $55,55 \%$, kehadiran $80,55 \%$, mengajukan pertanyaan $11.11 \%$, melihat video $77,77 \%$, sehingga rata-rata peningkatan keaktifan $47,22 \%$ menjadi $56,26 \%$. Peningkatan hasil belajar Fisika rata-rata pra siklus 59,42, siklus I rata-rata 78, pada siklus II rata-rata 89. Peningkatan keaktifan $55 \%$ dan hasil belajar peserta didik mencapai rata-rata lebih dari 80, maka penerapan kelasiber berbasis video pembelajaran perlu diterapkan dan diteruskan dalam pembelajaran karena adanya peningkatan keaktifan maupun hasil belajar.
\end{abstract}

Kata kunci: kelasiber, video pembelajaran, keaktifan, hasil belajar.

\section{Application of Kelasiber Based on Online Learning Videos to Increase Activeness and Learning Outcomes of Physics}

Abstarct: This Action Research aims to increase the activeness and learning outcomes of students in the XTP2 class of SMKN 3 Yogyakarta by implementing Kelasiber based on online learning videos of Physics for the Competence of Static and DC Electricity. This research was conducted in two cycles, each cycling consisting of two meeting, each meeting with a time allocation of two lesson hours. Each cycle includes, namely planning, acting, observing and reflecting. Kelasiber Based on online learning Videos with steps of Inform the Kelasiber, Search for Learning Videos, Students Watching Videos, Doing Exercise, Teachers analyze Activeness and Learning Outcomes, Feedback on Learning Results. Activeness is measured by: punctual attedance, attedance, asking questions, and watching videos, while the aspects of learning achievement are measured from the test. The Results showed that the increase in activeness in cycle I, punctuality of $61.11 \%$, presence of $72.22 \%$, asking questions of $5.56 \%$, view video $44.44 \%$, in cycle II of punctuality of $55.55 \%$, presence of $80,55 \%$, asking questions $11.11 \%$, view video $77.77 \%$, so that the average is 59.42, cycle 1 has an average of 78, in cylce 2 it average 89. The increase in activeness is 55\% and student learning outcmes average above 80, so the application of learning videos-based Kelasiber needs to be applied and continued in learning because of an increase in both activeness and achievement of learning outcomes.

Keywords: kelasiber, learning videos, activeness, learning outcomes.

\section{Pendahuluan}

Guru menjadi ujung tombak pendidikan yang mempunyai tugas mulia membekali para generasi serta memberikan wawasan ke depan kepada peserta didik. Dalam kebijakan merdeka belajar mereka dipandang sebagai pusat belajar. Peserta didik belajar dari rumah sudah punya hal ihwal wawasan dan pengalaman, yang bisa diperoleh dari berbagai referensi diantaranya dari gadget, e-book, e-modul, e-diktat, dan video pembelajaran online yang dapat diakses dengan hotspot area yang ada dimanapun, dan kapanpun. Peran guru selain sebagai sumber belajar, juga sebagai fasilitator dalam mendesain kebutuhan 
sumber belajar yang dibutuhkan peserta didik. Belajar dengan beragam sumber belajar akan menumbuhkembangkan potensi peserta didik.

Pada masa pandemi Covid-19, terjadi perubahan paradigma belajar dari peserta didik luar jaringan (luring) dengan tatap muka kemudian beralih menjadi dalam jaringan (online). Pembelajaran jarak jauh (PJJ) menjadi solusi dalam pembelajaran, masalah belajar dapat dipecahkan dengan cara berdiskusi dalam grup medsos terutama WhatssApp (WA) dan aplikasi media sosial yang lain untuk mendapatkan tujuan belajar. Tugas utama pendidik mengarahkan belajar memfasilitasi, dan melayani pembelajaran yang menyenangkan bagi peserta didik.

Penelitian dilakukan di SMKN 3 Yogyakarta bahwa sebagian Peserta didik kurang tertarik dan bertendensi pasif dalam belajar terutama dalam situasi pandemi Covid-19. Peserta didik dalam menyelesaikan tugas tidak maksimal, antara lain: peserta didik masih tergantung dengan kawannya lewat kiriman WA, malu mengemukakan pendapat, tugas cenderung saling menunggu, tidak online dalam presensi.

Hasil capaian nilai akhir semester ganjil Tahun Pelajaran 2020/2021 didapat data:

Tabel 1. Data hasil penilaian akhir semester ganjil

\begin{tabular}{ccccc}
\hline No & Kelas & $\begin{array}{c}\text { Kehadiran } \\
\text { rata-rata } \\
\text { Semester } \\
\text { Ganjil }\end{array}$ & $\begin{array}{c}\text { Rata- } \\
\text { Rata } \\
\text { PAS }\end{array}$ & $\begin{array}{c}\text { Ketuntasan } \\
\text { belajar }\end{array}$ \\
\hline 1 & XTL2 & $91 \%$ & 61,43 & $22,22 \%$ \\
2 & XTL3 & $92 \%$ & 72,59 & $58,33 \%$ \\
3 & XTP1 & $81 \%$ & 64,48 & $27,78 \%$ \\
4 & XTP2 & $79 \%$ & 59,52 & $25,00 \%$ \\
\hline
\end{tabular}

Dengan memperhatikan Tabel 1, dari kehadiran dan hasil belajar terendah adalah kelas XTP2, maka kondisi di atas dibutuhkan strategi, metode dan model pembelajaran untuk meningkatkan keaktifan dan hasil belajar Fisika bagi peserta didik di SMK. Oleh sebab itu melalui penelitian 'Kelasiber berbasis video pembelajaran daring Fisika untuk meningkatkan keaktifan dan hasil belajar peserta didik kelas XTP2 di SMKN 3 Yogyakarta Tahun Pelajaran 2020/2021" akan menjadi solusi alternatif yang efektif.

Dari latar belakang masalah yang dilakukan pengamatan di SMK N 3 Yogyakarta, maka masalah dapat diidentifikasi bahwa peserta didik belajar tidak antusias terhadap mata pelajaran Fisika terlihat dari kehadiran yang tidak optimal, peserta didik dalam pembelajaran kecenderungannya pasif tidak ada ide untuk bertanya, menanggapi, mengkritik, terhadap substansi materi, metode, dan model pembelajaran, hasil belajar dan kemauan peserta didik masih rendah, ditunjukkan rata-rata 59,52, peserta didik tidak mandiri dalam menyelesaikan tugas, masih menunggu jawaban temannya karena tidak percaya diri atas jawaban sendiri, peserta didik terlambat dalam menyelesaikan tugas Fisika.

Batasan masalah dalam penelitian ini adalah Kelasiber dipilih sebagai solusi di kelas XTP2 sebab karakteristiknya peserta didik yang pasif, sangat penting meningkatkan keaktifan dan hasil belajarnya.

Rumusan masalah penelitian ini: (1) bagaimana belajar mengajar Fisika dengan penerapan kelasiber berbasis video pembelajaran daring dapat meningkatkan keaktifan peserta didik kelas XTP2 di SMKN 3 Yogyakarta? (2) bagaimana belajar mengajar Fisika dengan penerapan kelasiber berbasis video pembelajaran daring dapat meningkatkan hasil belajar peserta didik kelas XTP2 di SMKN 3 Yogyakarta?

Tujuan penelitian untuk meningkatkan keaktifan peserta didik kelas XTP2 di SMKN 3 Yogyakarta melalui penerapan kelasiber berbasis video pembelajaran Fisika dan meningkatkan hasil belajar peserta didik kelas XTP2 di SMKN 3 Yogyakarta melalui penerapan kelasiber berbasis video pembelajaran daring.

Manfaat penelitian bagi peserta didik: pembelajaran daring yang mengasyikan, memperoleh pengalaman dan wawasan baru, meningkatkan keaktifan dan hasil belajar. Manfaat bagi guru: alternatif model pembelajaran daring dengan peran guru memfasilitasi dan mengevaluasi, mutu guru dapat meningkat, menambah perkayaan praktik mengajar. Bagi instansi sekolah: performance sekolah dapat meningkat karena dengan penelitian, mutu pendidikan di sekolah akan selalu diperbaiki, meningkatkan kompetitif dengan sekolah lain, sehingga peningkatan keaktifan dan prestasi stakeholder akan tercipta. Bagi masyarakat: dapat pengimbasan tentang kreativitas yang tinggi untuk diterapkan.

Mapel Fisika bagian adaptif yang sekarang menjadi kelompok $\mathrm{C} 1$ peminatan bertujuan memberi bekal peserta didik sebagai basic pengetahuan tentang kaidah alam sebagai dasar juga syarat kemampuan yang difungsikan mengawal peserta didik untuk mencapai kompetensinya. Penguasaan mapel Fisika memberi kemudahan peserta didik menganalisa berbagai proses terkait berdasarkan kinerja alat yang digunakan untuk support pembentukan program keahlian.

Dapat disimpulkan bahwa pembelajaran Fisika merupakan komunikasi antara peserta didik, guru dan perangkat ajar pada lingkungan 
alam, kompetensi untuk penelitian ini tentang listrik startis dan listrik DC. Pemberian materi ini karena berupa konsep dan fakta, sebab itu penting dalam menerapkan kelasiber berbasis video pembelajaran, agar peserta didik mendapat pengalaman belajar tentang listrik statis dan DC.

E-learning atau kelas maya SMKN 3 Yogyakarta untuk mendukung pembelajaran secara daring, diharapkan dapat mewujudkan visi sekolah dengan terwujudnya tamatan yang beriman, unggul, berjiwa wirausaha, berbudaya dan berwawasan lingkungan.

Kelasiber adalah E-learning atau salah satu Learning Content management System atau akronim LCMS, yang digunakan untuk sistem pembelajaran jarak jauh (PJJ) di SMKN 3 Yogyakarta (Gambar 1).

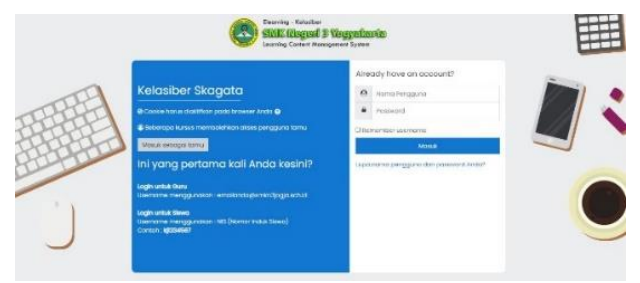

Gambar 1. Tampilan Kelasiber

Peserta bergabung sejumlah 2120, 652 kursus, 5787 aktivitas. Peserta didik dan guru bisa masuk ke sistem E-learning Kelasiber dengan akun yang diberikan atau dibuat. (Kelasiber. Skagata.sch.id)

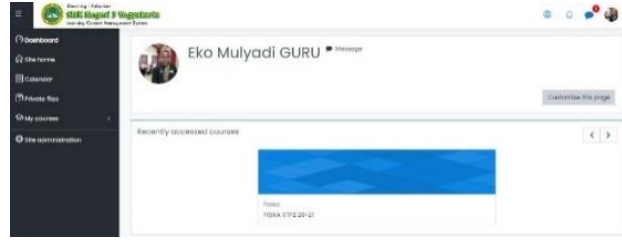

Gambar 2. Dashboard Kelasiber

Dalam sistem kelasiber guru bisa memasukan materi dalam bentuk Word, PDF, $J P G, P P T$, Quiz, dimasukan ke dalam kelasiber bahkan video pembelajaran $m p 4$.

Kemudian yang diperoleh dengan kelasiber, peserta didik bisa mengerjakan latihan-latihan soal ulangan formatif, ulangan tengah semester dan akhir semester, bisa diketahui waktu mengerjakan awal, akhir bahkan peserta didik langsung tahu nilainya. Bahkan bisa di setting mengerjakan berkali-kali sampai memenuhi ketuntasan minimal (KKM).

Sebuah media yang didesain dengan runtut yang berdasar kurikulum yang berlaku serta pengembangannya menerapkan prinsip-prinsip belajar sehingga program itu bagi peserta didik dapat memahami materi pelajaran lebih asyik dan mengasyikan. Produk Fisika VCD Pembelajaran sebuah program belajar yang dirancang dalam VCD dan diaktifkan menggunakan alat VCD Player serta Televisi. (Anna Merina, 2008).

Alat yang berfungsi menyampaikan kesan audio visual disebut media (Bove, 1997). Suatu alat yang digunakan menghantarkan pesan belajar dinamakan media ajar. Pembelajaran adalah suatu proses interaksi antara peserta didik, guru dan bahan ajar. Interaksi tidak akan berjalan tanpa bantuan alat penyampai pesan.

Wujud stimulan yang bisa dipergunakan sebagai alat pesan diataranya adalah komunikasi atau interaksi antar manusia, fakta, animasi statis atau dinamis, tulisan dan suara yang direkam. Lima bentuk stimulus ini akan membantu dalam mempelajari mapel Fisika. (Ouda Teda Ena, 2008).

Dapat disimpulkan video pembelajaran adalah euipment yang memiliki fungsi dalam memberikan pesan visual yang didesain secara terstruktur supaya peserta didik mampu memahami mapel secara mudah dan menyenangkan.

Belajar sebuah proses, dan bukan hanya hasil yang akan dicapai (Hamalik, 2009: 106). Belajar itu "perubahan", di internal diri seseorang sesudah berakhirnya aktivitas belajar (Djamarah, 2013). Menurut Hamalik (2009:197), aktivitas belajar merupakan berbagai macam aktivitas kegiatan yang diberikan pada target belajar dalam kondisi belajar dan mengajar.

Peserta didik dalam proses pembelajaran dimana belajar aktif menggali pengetahuan. Sesuai konsep "Cara Belajar Siswa Aktif" (CBSA), sistem belajar yang fokus pada keaktifan peserta didik secara ragawi, psikis, fikir, dan emosi agar mendapat hasil belajar dalam aspek koginisi, afeksi dan psikomotoris. CBSA merupakan proses pendekatan belajar yang terfokus pada keaktifan, merupakan core dari proses belajar (Hamalik, 2013: 137).

Dalam konsep cara belajar peserta didik aktif, proses belajar diimplementasikan dalam kegiatan seperti diskusi, mendengar, membuat proyek, problem solving, sharing ide, merecanakan proyek, dan sebagainya. Konsep tersebut merupakan model pembelajaran secara aktif. Menurut Amri (2015), Sebuah cara pembelajaran yang dapat membuat peserta didik menjadi aktif disebut pembelajaran aktif.

Pengertian belajar aktif adalah proses belajar dimana guru mampu membuat susasana supaya peserta didik aktif untuk bernalar kritis, dengan bertanya dan mengemukakan idenya. Aktivitas belajar di dalam kelas akan terwujud apabila ada komunikasi aktif antar warga kelas (Uno, 2013: 106). Proses belajar disebut aktif jika 
mengandung: 1) Kelekatan tugas, 2) Tanggungjawab, 3) Termotivasi (Daryanto, dkk, 2007:208-209).

Berdasarkan beberapa definisi keaktifan tersebut dapat dibuat kesimpulan, keaktifan peserta didik adalah semua aktivitas oleh peserta didik untuk melakukan komunikasi dengan sekitar. Dalam kontek ini peserta didik lebih aktif untuk belajar bukan sematan menerima materi dari guru tetapi harus membaca, menulis dan berdiskusi.

Aktivitas belajar peserta didik menurut Daryanto, dkk (2012: 2) dibagi menjadi 2 yakni aktivitas fisik maupun psikis yang diklasifikasikan : 1) Berupa aktivitas visual contohnya senang membaca, menulis, melakukan demonstrasi dan percobaan, 2) Aktivitas dengan lisan seperti suka cerita, bersajak, menyanyi, diskusi, tanggung jawab, 3) Berupa aktivitas aktif mendengar contoh mendengar ceramah, penjelasan dari guru, pengarahan. 4) Aktivitas kinestetik contohnya melukis, menari, senam, atletik, 5) Aktivitas tulis contoh membuat surat, membuat makalah, mengarang.

Jenis aktivitas peserta didik menurut Kosasih (2015:8) terdiri dari: 1) Aktivitas raga contohnya kegiatan mendengar, meraba, berperan, dan aksi jasad yang lain, 2) Aksi psikis, contohnya dengan merespon, menilai, menyimpulkan, bertanya, memikirkan, 4) Aktivitas bersosial, contohnya dengan kerjasama, berdiskusi, dan simpati.

Beberapa pengertian di atas dapat disimpulkan keaktifan adalah suatu aksi yang dikerjakan oleh peserta didik. Aktivitas raga yang dikerjakan oleh peserta contohnya bertanya, menulis, membaca, mempunyai pendapat dan lainnya. Penelitian ini variabel yang akan digunakan menyesuaikan dengan mapel Fisika yaitu pada materi listrik statik dan Listrik DC.

Variabel untuk penelitian tindakan ini ranah keaktifan yang digunakan: 1) Kehadiran tepat waktu, 2) Kehadiran, 3) mengajukan pertanyaan, pendapat dan 4) melihat video.

Dalam kegiatan belajar mengajar selalu mendapatkan hasil belajar. "Hasil" menurut Kamus Besar Bahasa Indonesia pada edisi ke-2 adalah hal yang dibuat atau dijadikan usaha. Hasil belajar adalah perbuatan, sikap, pengertian, nilai, apresiasi, dan keterampilan (Suprijono, 2016: 5). Hasil belajar adalah pemahaman peserta didik setelah terjadi interaksi belajar (Sudjana, 2014: 22). Pendapat Susanto (2013: 5), Pemahaman yang didapat peserta didik sesudah mengikuti aktivitas pembelajaran disebut hasil belajar peserta didik. Seiring pendapat dari Jihad (2008:14) tentang definisi hasil belajar, wujud berubahnya sikap dari kognisi, afeksi dan psikomotoris dari suatu proses belajar dalam durasi tertentu merupakan pencapaian hasil belajar. Reigeluth (1983) dalam suprihatiningrum, (2016: 37), hasil belajar merupakan kerja yang ditandai sebagai sebuah kemampuan yang telah didapat.

Berdasarkan definisi di atas, dapat dirangkum hasil belajar itu kemampuan peserta didik setelah melakukan proses belajar-mengajar dalam durasi tertentu.

Menurut Howard Kingsley dalam Sudjana (2014: 22) ada 3 jenis hasil belajar yakni 1) kebiasaan dan keterampilan, 2) pengertian dan pengetahuan, 3) cita-cita dan sikap.

Pendapat Sukiman (2012: 55-72), obyek evaluasi proses belajar meliputi hasil belajar aspek kognisi, afeksi dan psikomotoris. Hasil belajar kognisi mencakup kegiatan otak. Afeksi adalah hasil belajar yang terkait sikap, value dan minat. Psikomotoris adalah keterampilan gerak dan kapabilitas bertindak secara individu.

Dengan dasar definisi di atas dapat disintesis bahwa cara penilaian hasil belajar bergantung dari aspek belajar yang dinilai. Jika hasil belajar kognisi yang dinilai, maka cara penilaian digunakan butir soal. Sedangkan aspek afeksi berupa skala sikap maupun skala minat. Sedangkan untuk mengukur hasil belajar psikomotoris menggunakan tes praktik.

Era Pandemi Covid-19 merubah tatanan baru termasuk pendidikan, untuk mencegah menularnya Covid-19, pemberlakuan pembelajaran jarak jauh (PJJ), sehingga peserta didik belajar dari rumah. Guru menggunakan berbagai macam aplikasi yang diterapkan sesuai kemampuan guru menggunakan.

Kondisi Pandemi covid-19 menyebabkan peserta didik kecenderungan memiliki keaktifan dan hasil belajar menurun, sehingga rendahnya kedua variabel itu perlu diteliti dengan tindakan kelas secara virtual, agar dapat meningkatkan khususnya keaktifan dan hasil belajar.

Dalam penggunaan aplikasi yakni Kelasiber didalamnya bisa diinputkan link video pembelajaran, google form dan quiz untuk latihan maupun ulangan, sedangkan utamanya adalah WhatsApp grup yang selalu digunakan untuk berkomunikasi dengan peserta didik (Gambar 3).

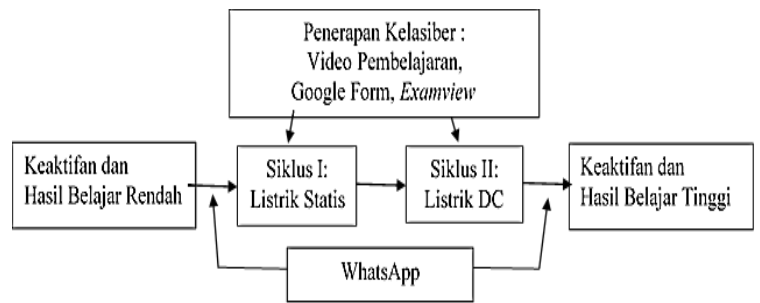

Gambar 3. Kerangka Berfikir 


\section{Metode Penelitian}

Penelitian dilakukan di SMKN 3 Yogyakarta, Jl.W. Monginsidi 2 Yogyakarta. Rencana tindakan didasarkan pada refleksi. Tindakan dilakukan mulai tanggal 19 Januari sampai 30 Maret 2021. Penelitian dilaksanakan setiap hari Selasa pada sesi 2 pukul 9.00-10.30 WIB dengan durasi 2x45 menit.

Setting penelitian dilakukan di dalam kelasiber.id: membuat latihan soal materi listrik statis dan listrik DC dengan quiz dan google form, untuk dikerjakan peserta didik sekaligus untuk presensi, membuat video pembelajaran, edit video, upload video ke Youtube, memasukkan link video, quiz dan google form ke kelasiber.id.

Saat pelaksanaan: peserta didik login ke kelasiber.id, membuka link video dan menyaksikan, subscribe, like dan comment, selanjutnya mengerjakan latihan, guru merekapitulasi keaktifan terutama partisipasi kehadiran dan keaktifan bertanya melalui WA grup, berikutnya merekapitulasi nilai yang diperoleh peserta didik sebagai variabel hasil belajar.

PTK ini dilakukan di kelas XTP2 semester genap tapel 2020/2021, subjek penelitian dengan jumlah peserta didik 36 orang.

Jenis Penelitian ini adalah Class Action Research model oleh Kemmis dan Mc Taggart (1990:14), dalam Suharsimi Arikunto (2006:16) dan Yoko Rimy (2008:12) diuraikan dalam Gambar 4, sebagai berikut.

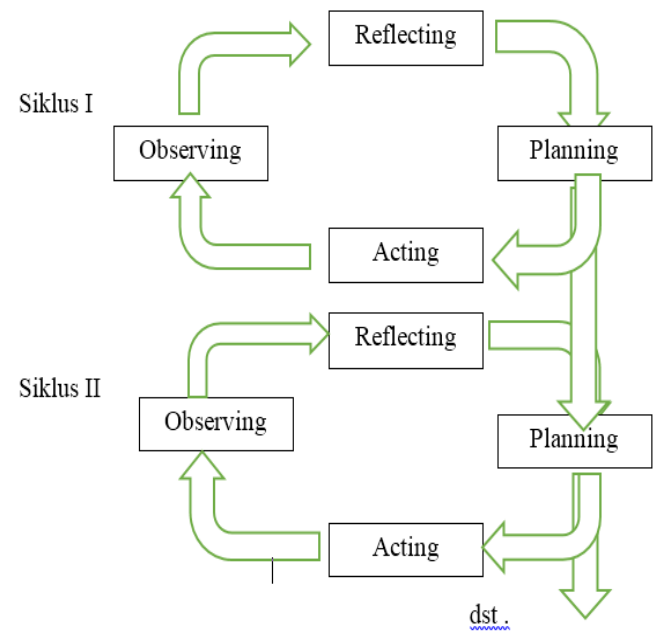

Gambar 4. Siklus penelitian tindakan model Kemmis dan Taggart.

Perencanaan tindakan yang dikerjakan dengan 2 siklus, setiap siklus, 2 kali tatap muka 2x45 menit. Setiap siklus melalui 4 tahapan, yakni: perencanaan, pelaksanaan, pengamatan dan refleksi. Perencanaan dikerjakan pada tiap kali pertemuan dengan satu siklus.
Siklus I: 1) Perencanaan: mempersiapkan perangkat ajar, silabus, RPP, video pembelajaran listrik statis 1: Hukum Coloumb, medan listrik, soal quiz, google form, learning management system, kelasiber.id, menyiapkan informasi di WA grup kelas untuk publikasi pembelajaran listrik statis: muatan, Hukum Coloumb, medan listrik, potensial listrik, energi potensial listrik dan kapasitor.

Pelaksanaan Pertemuan 1: Guru mengomunikasikan tujuan pembelajaran tentang kompetensi listrik statis yang harus diraih dan penugasan yang akan dilakukan melalui informasi WA grup, peserta didik masuk kelasiber.id mendownload video pembelajaran listrik statis 1: Muatan dan Hukum Coloumb, peserta didik mengerjakan latihan melalui quiz di kelasiber, peserta didik submit all dipastikan langsung mengetahui hasil pekerjaannya, guru merekapitulasi kehadiran, peserta didik aktif dan nilai sebagai hasil belajar.

Pertemuan 2: Guru mengomunikasikan tujuan pembelajaran tentang kompetensi listrik statis 2: medan listrik, potensial listrik, energi potensial listrik dan kapasitor yang harus dicapai dan garis besar tugas yang akan diberitahukan melalui WA grup, peserta didik masuk kelasiber.id mendownload video pembelajaran listrik statis 2: medan listrik, potensial listrik, dan kapasitor, peserta didik mengerjakan latihan dengan melalui link google form dikelasiber, peserta didik submit all dipastikan langsung mengetahui hasil pekerjaannya, guru merekapitulasi kehadiran, peserta didik aktif dan nilai sebagai hasil belajar.

Pengamatan: kegiatan pengamatan dilakukan guru peneliti dan kolaborator terhadap keaktifan peserta didik dalam pengerjaan tugas baik quiz maupun google form. Pengerjaan tugas dilihat ketepatan waktu, sekaligus juga bisa sebagai kehadiran peserta didik, dan nilai hasil pekerjaan, tentang daya serap dan jumlah ketuntasan yang dicapai peserta didik.

Refleksi diakhir siklus I pengamatan terhadap hasil keaktifan dan hasil belajar peserta didik dengan kelasiber video, quiz dan link google form yang akan diperbaiki pada siklus selanjutnya.

Pengumpulan data dilakukan dengan instrumen keaktifan: (1) kehadiran tepat waktu, yang diisi melalui quiz kelasiber dan google form, (2) mengajukan pertanyaan, konfirmasi, kritik melalui WA, comment, subscribe, like, (3) ketepatan menggumpulkan tugas dalam durasiyang ditentukan.

Sedangkan untuk hasil belajar dilihat dari: (1) hasil nilai yang dicapai peserta didik, (2) daya 
serap peserta didik dalam satu kelas, (3) persentase ketuntasan yang dicapai peserta didik.

Dan seterusnya, siklus kedua mirip dengan prosedur siklus I, tetapi dengan materi Fisika listrik DC: Kuat Arus, Hukum Ohm, Hukum Kirchoff I, Rangkaian Seri Pararel Hambatan, Sumber Tegangan dan Daya Listrik.

Penelitian Tindakan Kelas ini berhasil jika ada peningkatan dengan Keaktifan mencapai $55 \%$, dan hasil belajar dengan nilai rata-rata 80 , maka siklus dihentikan.

\section{Hasil dan Pembahasan Deskripsi Pra Siklus}

Kondisi awal pra tindakan kelas XTP2, dengan jumlah peserta didik 36 putra. Di dalam proses pembelajaran Fisika secara daring, peserta didik kurang antusias, terlihat dari partisipasi peserta didik yang mengisi daftar hadir, menyelesaikan tugas, mengajukan pertanyaan baik lisan maupun tertulis, masih ada nuansa segan dan tidak percaya diri.

Pembelajaran Fisika secara daring setiap hari Selasa, sesi 2 pukul 09.00-10.30 WIB, peserta didik tidak menunjukkan antusia dan kecenderungan pasif, sebagian kecil yang aktif. Dampak dari keadaan di atas meunjukkan hasil belajar yang tidak optimal (Tabel 2).

Tabel 2. Hasil ulum semester ganjil maple Fisika XTP2 tahun Pelajaran 2020/2021

\begin{tabular}{lc}
\hline Hasil Belajar/Nilai & Hasil Ulum Fisika \\
\hline Minimal & 13 \\
Maksimal & 80 \\
Persen Ketuntasan & $9(25 \%)$ \\
Rerata & 59,42 \\
Daya Serap & $25 \%$ \\
\hline
\end{tabular}

Dari Tabel 2 memperlihatkan hasil ulum semester ganjil berbasis android tapel 2020/2021, nilai tertinggi 80, nilai minimum 13 dengan rerata 59,42, Persen tuntas 25\%, diatas 75 (KKM), sedangkan daya serap 25\%. Hasil belajar Fisika sangat minim dan tidak optimal.

\section{Deskripsi Siklus I}

Di dalam perencanaan tindakan guru menyiapkan instrumen Rencana Pelaksanaan Pembelajaran, dengan penerapan kelasiber berbasis video pembelajaran daring, dua kali pertemuan, pertemuan pertama: guru membagikan informasi pembelajarandi WA grup, peserta didik masuk kelasiber, melihat video gaya listrik dan medan magnet, peserta didik memahami materi dari video pembelajaran, peserta didik mengerjakan latihan listrik statis, guru merekapitulasi presensi, nilai hasil latihan (hasil belajar), ketuntasan dan daya serap.

Pertemuan kedua: guru membagikan informasi pembelajaran di WA grup, peserta didik masuk kelasiber menuju materi listrik statis 2, melihatvideo energi potensial dan kapasitor, peserta didik mengerjakan latihan listrik statis 2, link google form, guru merekapitulasi presesnis, nilai hasil latihan (hasil belajar), ketuntasan, daya serap dan masukan peserta didik, apakah peserta didik senang dengan kelasiber, apakah peserta didik paham dan menerapkan dalam kehidupan sehari-hari.

Guru menyiapkan instrumen RPP, form kaktifan, naskah soal tes baik melalui kelasiber atau link google form kelasiber, form pengamatan dan hasil belajar maple Fisika peserta didik dari pra siklus, siklus I, siklus II dst.

Pelaksanaan tindakan dilakukan sesuai dengan RPP. Di awal pertemuan guru menjelaskan target dan step pembelajaran dengan kelasiber berbasis video pembelajaran, latihan baik langsung di kelasiber maupun google form untuk latihan.

Pertemuan kedua: Guru membagikan informasu pemberitahuan pembelajaran di WA grup peserta didik, peserta didik membaca informasi, peserta didik mneyaksikan video, memahami penyampaian materi melalui kelasiber berbasis video pembelajaran, setelah menyaksikan tayangan video, peserta didik mengerjakan soal di kelasiber.

Hasil pengamatan aspek keaktifan pada siklus I yaitu ada 4 aspek keaktifan peserta didik yang diukur: (1) ketepatan waktu, (2) kehadiran, (3) mengajukan pertanyaan dengan tulisan, (4) melihat video, aspek kehadiran peserta didik selama mengikuti pembelajaran daring, dengan kelasiber berbasis video pembelajaran.

Tabel 3. Keaktifan peserta didik per pertemuan pada siklus I

\begin{tabular}{|c|c|c|c|c|}
\hline \multirow{2}{*}{ No } & \multirow{2}{*}{ Keaktifan } & \multicolumn{2}{|c|}{ Siklus I (\%) } & \multirow{2}{*}{$\begin{array}{c}\text { Rata-rata } \\
\text { per item }\end{array}$} \\
\hline & & $\begin{array}{c}\text { Kelasiber } \\
\text { Quiz }\end{array}$ & $\begin{array}{c}\text { Google } \\
\text { Form }\end{array}$ & \\
\hline 1 & $\begin{array}{l}\text { Ketepatan } \\
\text { Waktu }\end{array}$ & 16 & 27 & $\begin{array}{c}22 \\
(61,11 \%)\end{array}$ \\
\hline 2 & Kehadiran & 22 & 30 & $\begin{array}{c}26 \\
(72,22 \%)\end{array}$ \\
\hline 3 & $\begin{array}{l}\text { Mengajukan } \\
\text { pertanyaan } \\
\text { dengan } \\
\text { tulisan }\end{array}$ & 2 & & $\begin{array}{c}2 \\
(5,56 \%)\end{array}$ \\
\hline 4 & $\begin{array}{l}\text { Melihat } \\
\text { Video }\end{array}$ & 16 & & $\begin{array}{c}16 \\
(44,44 \%)\end{array}$ \\
\hline & $\begin{array}{l}\text { Rata-rata } \\
\text { Keaktifan }\end{array}$ & \multicolumn{3}{|c|}{$17(47,22 \%)$} \\
\hline
\end{tabular}


Pada Tabel 3 menunjukkan rata-rata keaktifan peserta didik sebesar 47,22\%, dengan ketepatan waktu kehadira pada pukul 09.0010.30 WIB, mengerjakan tugas meskipun di luar waktu pembelajaran daring tetap dianggap hadir. Keberanian peserta didik mengajukan pertanyaan sangat rendah, hanya $5,56 \%$, peserta didik perlu dilatih untuk keterampilan bertanya. Tabel 4.

Hasil belajar pada siklus I ditunjukkan pada

Tabel 4. Hasil Belajar Fisika pada Siklus I

\begin{tabular}{|c|c|c|c|c|}
\hline \multirow{3}{*}{$\begin{array}{c}\text { Hasil } \\
\text { Belajar }\end{array}$} & \multicolumn{4}{|c|}{ SIKLUS I } \\
\hline & \multirow{2}{*}{$\begin{array}{c}\text { Pra } \\
\text { Siklus }\end{array}$} & \multicolumn{3}{|c|}{ Latihan/Tugas } \\
\hline & & $\begin{array}{c}\text { Kelasi } \\
\text { ber } \\
\text { Quiz }\end{array}$ & $\begin{array}{l}\text { Google } \\
\text { Form }\end{array}$ & Rata-rata \\
\hline $\begin{array}{l}\text { Nilai } \\
\text { Minimum }\end{array}$ & 13 & 10 & 10 & 10 \\
\hline $\begin{array}{l}\text { Nilai } \\
\text { Maksimum }\end{array}$ & 80 & 90 & 100 & 95 \\
\hline Ketuntasan & $\begin{array}{c}9 \\
(25 \%)\end{array}$ & 9 & 24 & $\begin{array}{c}16,5 \\
(45,83 \%)\end{array}$ \\
\hline $\begin{array}{l}\text { Nilai Rata- } \\
\text { rata }\end{array}$ & 59,42 & 63 & 93 & 78 \\
\hline $\begin{array}{l}\text { Penguatan } \\
\text { (gain) }\end{array}$ & \multicolumn{4}{|c|}{18,58} \\
\hline
\end{tabular}

Dari Tabel 4 menunjukkan peningkatan nilai rata-rata dari 59,42 menjadi 78 dan peningkatan ketuntasan peserta didik dari $25 \%$ menjadi $45,83 \%$. Hal ini menunjukkan penerapan kelasiber berbasis video pembelajaran dapat meningkatkan hasil belajar Fisika materi listrik statis. Berdasarkan tabel 3 dan tabel 4 hasil tersebut belum memenuhi indikator keberhasilan.

Refleksi pada siklus I bahwa penerapan kelasiber berbasis video pembelajaran, keaktifan dan hasil belajar peserta didik dengan kelasiber video, quiz dan link google form, partisipasi peserta didik melihat video dan kemampuan mengajukan pertanyaan masih rendah, sehingga perlu adanya stimulus agar peserta didik mempunyai kepercayaan diri untuk bertanya, dan melihat video dengan memahami konten materi.

Sedangkan hasil latihan sebagai hasil belajar dengan kelasiber quiz dan link google form yang dimasukan dalam kelasiber hasilnya lebih optimal menggunakan link google form, terlihat dari nilai rata-rata dan ketuntasan yang diperoleh.

\section{Deskripsi Siklus II}

Planning tindakan dari refleksi siklus I, maka perencanaan yang dikerjakan adalah membuat pemberitahuan pembelajaran peserta didik dengan kelasiber, mengingakan peserta didik agar selalu memahami pembelajaran materi listrik DC, dengan melihat video dan menstimulus peserta didik agar mau bertanya di dalam grup WA.

Pelaksanaan tindakan, pada pertemuan pertama siklus II, membagikan pemberitahuan kepada peserta didik tentang pembelajaran Fisika dengan penerapan kelasiber berbasis video tentang kuat arus dan Hukum Ohm.

Hasil pengamatan siklus II tentang aspek hasil keaktifan dilaksanakan 2 kali pertemuan, rekapitulasi hasil keaktifan (Tabel 5).

Tabel 5. Keaktifan peserta didik per pertemuan pada siklus II

\begin{tabular}{|c|c|c|c|c|}
\hline \multirow[b]{2}{*}{ No } & \multirow[b]{2}{*}{ Keaktifan } & \multicolumn{2}{|c|}{ Siklus I (\%) } & \multirow[b]{2}{*}{$\begin{array}{c}\text { Rata-rata } \\
\text { per item }\end{array}$} \\
\hline & & $\begin{array}{c}\text { Kelasiber } \\
\text { Quiz }\end{array}$ & $\begin{array}{c}\text { Google } \\
\text { Form }\end{array}$ & \\
\hline 1 & $\begin{array}{l}\text { Ketepatan } \\
\text { Waktu }\end{array}$ & 16 & 24 & $\begin{array}{c}20 \\
(55,55 \%)\end{array}$ \\
\hline 2 & Kehadiran & 29 & 29 & $\begin{array}{c}29 \\
(80,55 \%)\end{array}$ \\
\hline 3 & $\begin{array}{l}\text { Mengajukan } \\
\text { pertanyaan } \\
\text { dengan } \\
\text { tulisan }\end{array}$ & \multicolumn{2}{|l|}{4} & $\begin{array}{c}4 \\
(11,11 \%)\end{array}$ \\
\hline 4 & Melihat Video & \multicolumn{2}{|c|}{28} & $\begin{array}{c}28 \\
(77,78 \%) \\
\end{array}$ \\
\hline $\mathrm{Ra}$ & -rata Keaktifan & \multicolumn{3}{|c|}{$20,25(56,25 \%)$} \\
\hline
\end{tabular}

Tabel 5 menunjukkan rata-rata keaktifan peserta didik $56,25 \%$, ada peningkatan keaktifan pada siklus I sebesar $47,22 \%$ terjadi penguatan sebesar 9,03\%. Kemampuan mengajukan pertanyaan dan melihat video ada peningkatan.

Hasil belajar pada siklus II pada hasil tes tentang listrik DC direkapitulasi diperoleh Tabel 6 berikut.

Tabel 6. Hasil Belajar Fisika pada Siklus II

\begin{tabular}{|c|c|c|c|c|}
\hline \multirow{3}{*}{$\begin{array}{l}\text { Hasil } \\
\text { Belajar }\end{array}$} & \multicolumn{4}{|c|}{ Siklus II } \\
\hline & \multirow[b]{2}{*}{ Siklus I } & \multicolumn{3}{|c|}{ Latihan/Tugas } \\
\hline & & $\begin{array}{l}\text { Kelasi } \\
\text { ber } \\
\text { Quiz }\end{array}$ & $\begin{array}{c}\text { Kelasib } \\
\text { er } \\
\text { Google } \\
\text { Form }\end{array}$ & Rata-rata \\
\hline $\begin{array}{l}\text { Nilai } \\
\text { Minimum }\end{array}$ & 10 & 10 & 10 & 10 \\
\hline $\begin{array}{l}\text { Nilai } \\
\text { Maksimum }\end{array}$ & 95 & 90 & 100 & 95 \\
\hline Ketuntasan & $\begin{array}{c}16,5 \\
(45,8 \%)\end{array}$ & 25 & 28 & $\begin{array}{c}26,5 \\
(73,61 \%)\end{array}$ \\
\hline $\begin{array}{l}\text { Nilai Rata- } \\
\text { rata }\end{array}$ & 78 & 82 & 96 & 89 \\
\hline $\begin{array}{l}\text { Penguatan } \\
\text { (gain) }\end{array}$ & \multicolumn{4}{|c|}{11} \\
\hline
\end{tabular}


Tabel 6 menunjukkan hasil belajar siklus I, ketuntasan 45,83\%, nilai rata-rata diperoleh 78 , sedangkan hasil belajar siklus II, ketuntasan $73,61 \%$, nilai rata-rata diperoleh 89 juga ada kenaikan, sedangkan penguatan 11 .

Refleksi siklus II, terlihat seudah ada peningkatan keaktifan peserta didik XTP2, baik ketepatan waktu, kehadiran, kemampuan bertanya, dan melihat video. Namun untuk kemampuan bertanya tetap belu optimal masih perlu distimulus, agar ada rasa percaya diri peserta didik bisa mengajukan pertanyaan atau bernalar kritis, serta perlunya dibiasakan untuk mempunyai keterampilan bertanya. Begitu juga dengan hasil belajar, kemudahan menggunakan link google form dibanding dengan kelasiber quiz.

Pembahasan keaktifan siklus I dan siklus II direkapitulasi keaktifan pada siklus I dan siklus II ditunjukkan Gambar 5.

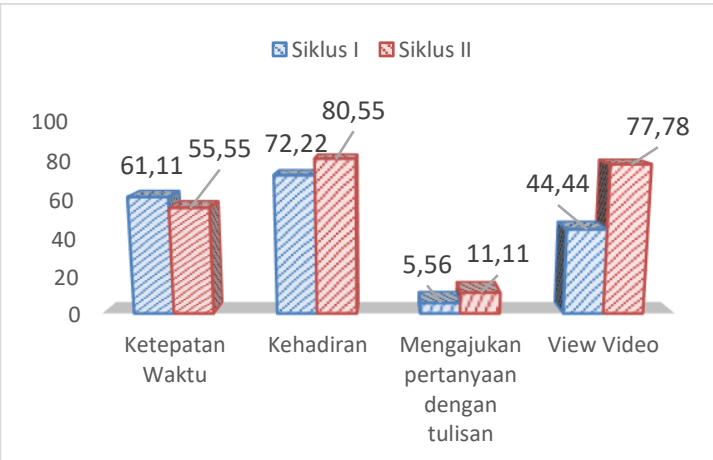

Gambar 5. Peningkatan Keaktifan Siklus I dan Siklus II

Gambar 5 menunjukkan peningkatan dan perubahan rata-rata keaktifan dari siklus I sebesar $47,22 \%$ menjadi $56,25 \%$ pada siklus II.

Pembahasan hasil belajar siklus I dan Siklus II diperoleh (Gambar 6).

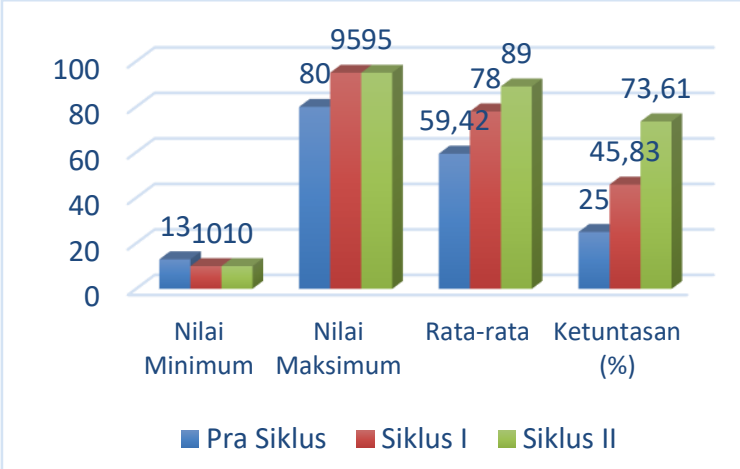

Gambar 6. Peningkatan hasil belajar Fisika Peserta Didik

Peningkatan rerata dan persen ketuntasan terjadi karena peserta didik membiasakan atau kebiasaan dengan kelasiber berbasis video pembelajaranbaik listrik statis memupun listrik DC, penggunaan learning management system (LMS) karena pembiasaan.

Penelitian Tindakan dihentikan pada siklus II, karena keaktifan diperoleh $56,25 \%$ sudah melebihi indikator keaktifan 55\% dan hasil belajar diperoleh 89 , juga sudah di atas indikator rata-rata 80 , maka siklus dihentikan.

\section{Simpulan dan Saran}

Berdasarkan penelitian dan pembahasan tersebut dapat disimpulkan, peningkatan keaktifan pada siklus I, ketepatn waktu sebesar $61,11 \%$, kehadiran 72,2\%, mengajukan pertanyaan 5,56\%, melihat video $44,44 \%$, sedagkan padan siklus II, ketepatan waktu sebesar 55,56\%, kehadiran 80,55\%, mengajukan pertanyaan $11,11 \%$, melihat video $77,77 \%$. Sehingga rata-rata peningkatan keaktifan 47,22\% menjadi 56,26\%.

Peningkatan hasil belajar Fisika rata-rata pra siklus 59,42, siklus I rata-rata 78, pada siklus II rata-rata 89. Peningkatan keaktifan 55\% dan hasil belajar peserta didik mencapai rata-rata di atas 80 , maka penerapan kelasiber berbasis video pembelajaran secara daring dapat meningkatkan keaktifan dan hasil belajar peserta didik kelas XTP2 di SMK N 3 Yogyakarta khususnya pada materi listrik statis dan listrik DC.

Tujuan PTK adalah memperbaiki dan mengembangkan proses belajar mengajar sehingga hasil belajar peserta didik bisa ditingkatkan, dan memotivasi guru untuk mencoba dengan penerapan kelasiber berbasis video pembelajaran untuk meningkatkan keaktifan dan hasil belajar Fisika. Guru dalam menyampaikan materi pelajaran secara daring, para guru hendaknya menyesuaikan aplikasi dan materi pelajaran dengan metode dan model pembelajaran yang dipergunakan.

\section{Daftar Pustaka}

Amri, Sofan. (2015). Implementasi Pembelajaran Aktif dalam Kurikulum 2013. Jakarta: Prestasi Pustaka Raya.

Arikunto, Suharsimi, dkk. (2006). Penelitian Tindakan Kelas. Jakarta: Bumi Aksara.

Bovee, Courland. (1997). Business Communication Today. New York: Pretince Hall.

Daryanto \& Mulio Rahardjo. (2012). Model Pembelajaran Inovatif. Yogyakarta: Penerbit Gava Media.

Daryanto \& Syaiful Karim. (2007). Pembelajaran Abad 21. Yogyakarta: Penerbit Gava Media.

Djamarah. (2013). Strategi Belajar Mengajar. Jakarta: Rineka Cipta. 
Hamalik, Oemar. (2009). Dasar-Dasar Pengembangan Kurikulum. Bandung: PT Remaja Rosdakarya.

Hamalik, Oemar. (2013). Kurikulum dan Pembelajaran. Jakarta: PT Bumi Aksara.

Hamalik, Oemar. (2013). Proses Belajar Mengajar. Jakarta:PT Bumi Aksara.

http://kelasiber.skagata.sch.id/ dipetik tanggal 29 Mei 2021.

Jihad, Asep \& Haris, Abdul. (2018). Evaluasi Pembelajaran. Jakarta: Multi Press.

Kosasih, E. (2015). Strategi Belajar dan Pembelajaran Impelmentasi Kuriklum 2013. Bandung: Penerbit Yrama Widya.

Merina, Anna. (2008). Pembelajaran Menggunakan Video CD Guna mengimbangi Tuntutan Pendidikan yang semakin komplek. Artikel 19 Mei 2008.

Ouda Teda Ena. (2008). Membuat Media Pembelajaran Interaktif dengan Piranti Lunak Presentasi. Yogyakarta: universitas Sanata Darma.
Rimy, Yoko. (2008). Penelitian Tindakan Kelas sebagai Bentuk Pengembangan Profesi Guru. Yogyakarta: LPMP.

Sudjana, Nana. (2014). Penilaian Hasil dan Proses Belajar Mengajar. Bandung: PT Remaja Rosda Karya.

Sukiman. (2012). Pengembangan Sistem Evaluasi. Yogyakarta: Insan Madani.

Suprihatiningrum, Jamil. (2016). Strategi Pembelajaran. Yogyakarta: Ar-Ruz Media.

Suprijono, Agus. (2016). Cooperative Learning. Yogyakarta: Pustaka Belajar.

Susanto, Ahmad. (2013). Teori Belajar dan Pembelajaran di Sekolah Dasar. Jakarta: Prenadamedia Group.

Tim Penyusun Kamus Pusat Bahasa. (1999). Kamus Besar Bahasa Indonesia Edisi ke-2. Jakarta: Balai Pustaka.

Uno, Hamzah B. \& Nurdin, Mohamad. (2013). Belajar dengan Pendekatan PAILKEM. Jakarta: PT Bumi Aksara. 